\title{
Sustainability Reporting by Local Councils in Coastal Regions: An Australian Study
}

\author{
Nick Sciulli \\ Associate for the Centre for Tourism and Services Research (CTSR) \\ School of Accounting \\ Victoria University \\ PO Box 14428 MCMC \\ Melbourne, Australia \\ Tel:(03) 9919-4424 E-mail:Nick.Sciulli@vu.edu.au
}

\begin{abstract}
The phrase social and environmental accounting research appears to have been superseded by the term sustainability reporting (SR). The Global Reporting Initiative (GRI) which is an internationally recognised reporting framework has developed sustainability reporting guidelines for specific industries including for the public sector. The objective of this investigation is to ascertain the type of sustainability reporting practices in six Local Councils located on the Australian coast line. A sustainability reporting disclosure index is developed and is calculated by comparing the disclosures provided by the Global Reporting Initiative with the annual reports of the six coastal councils. The findings suggest that these councils provide high disclosures for the categories of water and biodiversity and low disclosures for the categories of compliance and overall which records total environmental expenditures by type. Given that the reporting of sustainability practices by local councils is relatively new, it is expected that disclosures will increase over time. In addition, specialised sustainability reports are starting to be produced by local councils in addition to the statutory obligation of producing an annual report.
\end{abstract}

Keywords: Sustainability Reporting, Local Councils, Annual Reports JEL classifications: M41, M40 and M49 


\section{Introduction}

There is greater awareness and concern regarding an organisations activities and the effect it has on the environment. A substantial body of literature has now been developed under the commonly used term social and environmental accounting. However, it appears that a further expanding phase of research opportunities has emerged. The latest trend appears to favour the term sustainability reporting which implies an emphasis on organisations undertaking activities which continually nourish the adverse effect it may be having on the environment. It must also be recognised though, that there is currently no one universally accepted definition of sustainability and sustainability reporting (Moneva et.al. 2006).

Sustainability practices imply that the service or product can be produced over the long term whilst being sympathetic to the requirement to maintain or improve the environment at the same time. A simplified example would be the requirement of mining companies to account for restoration costs at the completion of their extraction activities. It is becoming apparent that other industries will also be held to account for the impact their activities are having and importantly, report on what these organisations are doing to counter these adverse consequences.

Accounting for climate change, carbon emissions and water management are just some of the areas that have become significant contemporary issues and will provide a rich pool of research opportunities for academics. Hopwood (2009) for example, sets out an array of possibilities for research in accounting and carbon markets. The work of Adams (2007), Gray (1995), Mathews (1997) and Deegan et.al (2000) have contributed significantly to this field of research and it is widely acknowledged that there are still many gaps in the literature, and hence, enormous opportunities for researchers to further engage in this important subject matter.

Of particular concern is the current dearth of research focusing on sustainability issues in the public sector. This has been noted by Ball and Grubnic (2007) with particular emphasis of the role of local governments in gaining community support for sustainable practices. Thus, although much of the focus to date has concentrated on the activities of large corporations, it is also becoming clear that sustainability problems can be worked on, and great advances made, at the individual or community level. Local governments appear to be best placed to connect sustainability issues with the community it serves.

\section{Literature review}

There have been several 'calls' for research into sustainability reporting in the public sector (Lewis 2008). As stated earlier, the use of annual reports to assess social and environmental disclosures is not a new phenomenon and has been used by several researchers to identify 'favourable' organisations (those with extensive social and environmental disclosures) as opposed to 'unfavourable' ones which have limited disclosures (Gray et al., 1995; Campbell 2000; Deegan et al. 2000; Moneva and Llena 2000; Wilmhurst and Frost 2000). 
There are several theories that can be used as a precursor to SR research. Institutional theory espouses that organisations tend to copy each other when practices become widely accepted and distributed amongst key players (Bebbington et.al. 2009). Legitimacy theory posits that social and environmental disclosures occur because of public pressure. Moreover, it is assumed that organisations with poor environmental credentials would provide more extensive positive environmental disclosures in an attempt to annul the offensive activity (Cho and Patten 2007). The theoretical model adopted for this project is a combination of legitimacy theory and given that the focus of the study is on the public sector, the notion of accountability is also relevant. That is, public sector agencies are accountable for their activities to a range of stakeholders, both internal and external to the organisation. However, it could be argued that this is identical to that of profit oriented firms, but one major difference is that the financial investment in the for profit sector is voluntary whereas in the public sector it is mandatory via the imposition of taxes. Hence, it is premised here that the accountability takes on an expanded dimension in the public sector.

In the case of legitimacy theory, the idea that organisations seek to be recognised as good corporate citizens by disclosing their activities that have a favourable effect on or seek to minimise damage to the environment is well established. In fact there is a strong case for suggesting that there are some particular limitations of analysing the contents of annual reports. This is because the disclosure of most environmental information is voluntary and therefore, it would be in the best interests of management to produce an annual report that would likely demonstrate skewness towards providing positive information. Perhaps more importantly, the promotion of transparency and accountability of an organisation is best achieved through in-depth interviews to assessing managerial motivations (Owen 2008). In addition, disclosures in annual reports is ex-post and therefore, certain activities that the community find sensitive may only reach the annual report if a widely reported incident has occurred.

Farneti and Guthrie (2009) undertook in-depth interviews across seven different public sector agencies in Australia. The agencies comprised of one federal government department, one state department, three local councils and two state public organisations. Twenty-five hours of interviews were undertaken to identify such issues as the reason for sustainability reporting in annual reports, how the agencies communicated sustainability issues, difficulties associated with using the GRI and who carried responsibility within the organisation for sustainability reporting. This study focussed on why organisations report on sustainability issues rather than what they report on. The findings suggest that that sustainability reports were mainly directed towards internal stakeholders, however, the annual report was a key communication device for external users. Further, a key individual in the organisation gave the impetus and motivation to pursue the path of sustainability reporting. Finally, in most cases these agencies had commenced with either triple bottom line (TBL) reporting or the balanced scorecard (BSC) before embarking on the GRI framework. The reason being that it had an international reputation which enhanced its legitimacy. 
The use of the BSC, the theory of intellectual capital (IC) and the GRI is also taken up by Yongvanich \& Guthrie (2006) who incorporate the positive aspects of all three models to develop an Extended Performance Reporting Framework (EPRF). They argue that:

The EPRF should enable companies to provide a more complete account of their extended performance. This should empower stakeholders, including shareholders, and help strengthen an organization's commitment to 'sustainability' (Yongvanich \& Guthrie 2006, p.318).

Whichever model or framework is adopted, it is clear that public sector agencies require guidance on how to best discharge their accountability to their stakeholders on the issue of sustainability activities. It may be the case that local government councils are already reporting on sustainability activities but as yet are not in a format to satisfy the ever growing demand from various interest groups. Given the sensitive nature of residing on the coast line this project seeks to investigate the incidence of sustainability reporting across six councils that have had significant population growth that has created concern amongst the community.

\section{Research method}

Six local councils situated in coastal regions were investigated. They were:

1. Bass Coast Shire Council

2. Mornington Peninsula Shire

3. Surf Coast Shire

4. Shoalhaven City Council

5. Wollongong City Council and

6. Maroochy Shire Council

Bass Coast, Mornington Peninsula and Surf coast Shire are located in Victoria, Shoalhaven and Wollongong in NSW and Maroochy in Queensland. These six councils were selected because they all reside on the coastline of Australia and have experienced large population growth putting pressure on the current infrastructure and the environment.

The 2007/2008 Annual Reports of these six coastal councils were downloaded from the internet and were adopted to gauge the extent of sustainability reporting. It was interesting to note how expansive the annual reports for these councils have become. They ranged in length from ninety-four pages to over two hundred pages.

The GRI Sustainability Reporting Guidelines (2006) also contain a Sector Supplement for Public Agencies which is a separate document but a component of the overall guidelines. This supplement was used as the benchmark against which the local council's annual reports were analysed. It has been recognised that although useful as a starting point, the GRI sustainability guidelines are by their nature, very general in application. Hence, sector supplements have also been produced based on various industry clusters such as mining and metals, automotive, food processing, telecommunications to name a few. Accordingly, 
By providing guidance on how to apply the GRI reporting framework in the context of public agencies, the Supplement makes a valuable contribution to achieving increased transparency in the public sector. Since all public agencies have some core sustainability performance issues in common, the Supplement has been designed for general use by public agencies operating in all tiers of government (GRI 2005, p.4).

Although following the GRI guidelines is voluntary, it is recognised internationally as the most comprehensive structured reporting framework currently available, and therefore, suitable for this project.

Under the environmental indicators there are ten major categories as illustrated in Table 1. There are also thirty-five (35) elements for which the guidelines provides a brief description of each (EN1 to EN35). These thirty-five elements are further classified as being either a core (CI) or additional (AI) indicator. Both CI and AI were scrutinised for in the annual reports. 


\section{Macrothink

Table 1 Public sector environmental performance indicators

\begin{tabular}{|c|c|c|c|c|}
\hline & Category & Description & $\begin{array}{l}\text { Core } \\
\text { Indicator } \\
\text { (CI) } \\
\text { Additional } \\
\text { Indicator } \\
\text { (AI) }\end{array}$ & Element \\
\hline 1 & Materials & $\begin{array}{l}\text { Total materials } \\
\text { use other than } \\
\text { water, by type. }\end{array}$ & $\begin{array}{l}\text { CI } \\
\text { CI }\end{array}$ & EN1,2 \\
\hline \multirow[t]{2}{*}{2} & Energy & $\begin{array}{l}\text { Direct and } \\
\text { Indirect energy } \\
\text { use. }\end{array}$ & CI & $\mathrm{EN} 3,4$ \\
\hline & & & $\mathrm{AI}$ & EN17,18,19 \\
\hline \multirow[t]{2}{*}{3} & Water & $\begin{array}{l}\text { Water use and } \\
\text { recycling }\end{array}$ & $\mathrm{CI}$ & EN5 \\
\hline & & & $\mathrm{AI}$ & EN20,21,22 \\
\hline \multirow[t]{2}{*}{4} & Biodiversity & $\begin{array}{l}\text { Location and } \\
\text { size }\end{array}$ & $\mathrm{CI}$ & EN6,7 \\
\hline & & & $\mathrm{AI}$ & EN23,24,25,26,27,28,29 \\
\hline \multirow[t]{2}{*}{5} & $\begin{array}{l}\text { Emissions, Effluents } \\
\text { and Waste }\end{array}$ & $\begin{array}{l}\text { Type and } \\
\text { amount }\end{array}$ & $\mathrm{CI}$ & EN8,9,10,11,12,13 \\
\hline & & & $\mathrm{AI}$ & EN30,31,32 \\
\hline 6 & Suppliers & $\begin{array}{l}\text { Environmental } \\
\text { performance of } \\
\text { suppliers }\end{array}$ & AI & EN33 \\
\hline 7 & $\begin{array}{l}\text { Products and } \\
\text { services }\end{array}$ & $\begin{array}{l}\text { Environmental } \\
\text { impacts }\end{array}$ & $\mathrm{CI}$ & EN14,15 \\
\hline 8 & Compliance & $\begin{array}{l}\text { Incidence of } \\
\text { fines }\end{array}$ & $\mathrm{CI}$ & EN16 \\
\hline 9 & Transport & $\begin{array}{l}\text { Environmental } \\
\text { impacts }\end{array}$ & $\mathrm{AI}$ & EN34 \\
\hline 10 & Overall & $\begin{array}{l}\text { Environmental } \\
\text { expenditures by } \\
\text { type }\end{array}$ & AI & EN35 \\
\hline
\end{tabular}

Content analysis was used to identify the incidence of disclosures falling under the ten categories listed in Table 1. Relatively speaking, content analysis is not a frequently used research technique in the accounting discipline. This may be because it has not been subjected to scrutiny by peer groups rather than from being a tool with insurmountable limitations. Some work has been conducted in corporate and social responsibility accounting and sustainability reporting in the public sector (Guthrie and Mathews 1985; Guthrie and Farneti 
2008). Although this current project was different to the Guthrie and Farneti (2008) study in that the latter investigated a combination of environmental and social elements, whilst this study focussed on all environmental elements.

Therefore, a rigid protocol was used to ensure that the coding rules were applied thus providing greater assurance that the analysis can be replicated. To validate the coding rules further, a research assistant was asked to fill in a number of the coding sheets after reviewing the submissions. It was found that there were no significant problems in understanding and filling in the coding sheets and that identical sustainability issues were noted by the assistant. A matrix was developed to note down the incidence of the ten categories across the six councils.

\section{Results and findings}

The results are tabulated to develop a sustainability reporting index (SRI), whereby the larger the index the greater the incidence of sustainability reporting.

Table 2. Total sustainability reporting disclosures by category.

\begin{tabular}{lllll}
\hline Category & $\begin{array}{l}\text { A= } \\
\text { number of } \\
\text { core and } \\
\text { additional } \\
\text { indicators } \\
\text { (see Table 1) }\end{array}$ & $\begin{array}{l}\text { B=Total } \\
\text { observations } \\
\text { from annual } \\
\text { reports }\end{array}$ & $\begin{array}{l}\text { C=Total } \\
\text { possible } \\
\text { observations } \\
(\mathbf{6 x A})\end{array}$ & $\begin{array}{l}\text { Index:D=SRDI } \\
(\mathbf{B} / \mathbf{C})\end{array}$ \\
\hline Materials & 2 & 2 & 12 & $17 \%$ \\
\hline Energy & 5 & 4 & 30 & $13 \%$ \\
\hline Water & 4 & 5 & 24 & $21 \%$ \\
\hline Biodiversity & 9 & 12 & 54 & $19 \%$ \\
\hline Emissions, Effluents & 9 & 7 & 54 & $13 \%$ \\
\& Waste & & 1 & 6 & $17 \%$ \\
\hline Suppliers & 1 & 1 & 12 & $8 \%$ \\
\hline Products \& Services & 2 & 1 & 6 & $0 \%$ \\
\hline Compliance & 1 & 0 & 6 & $33 \%$ \\
\hline Transport & 1 & 2 & 6 & $\mathbf{3 1 \%}$ \\
\hline Overall & 1 & 0 & $\mathbf{2 1 0}$ & \\
\hline Total & $\mathbf{3 5}$ & $\mathbf{6 5}$ & & 6 \\
\hline
\end{tabular}

The findings illustrated in Table 2 reveal that for these six councils, overall SR disclosures were low. The percentage disclosures ranged from a low of $0 \%$ for overall which is an indicator of total environmental expenditures by type to a high of $33 \%$ for transport, which measures significant environmental impacts of transportation used for logistical purposes. 
The higher SRDI are identified under the category water and biodiversity. With Australia and in particular Victoria experiencing the worst drought period on record, it is becoming apparent that stakeholders are demanding more information on water usage and recycling. For example, the Mornington Peninsula Shire report stated that:

The Shire helped deliver a shower-head exchange program, completed a Water Resource Management Plan...............the Shire secured a $\$ 300000$ grant to install rainwater tanks and water-efficient appliances at 23 sports pavilions. The project is expected to reduce water consumption at these sites by up to 60 per cent. (Mornington Peninsula Shire Annual Report 2008, p. 15)

Biodiversity also has a high SRDI. This could be explained by the fact that these six councils reside in environmentally sensitive areas with a rich mix of flora, fauna and marine life. Once more, stakeholders would require appropriate reporting on this category. For example, the annual report of Bass Coast Shire stated that:

\footnotetext{
The preparation of the Environment Sustainability Plan is a major step to ensuring that this community can retain their quality of life. This is a priority for council. The plan identifies local priority issues for the natural environment, which are:

Biodiversity, managing our beaches and bushland reserves, climate change impacts and adaptations. (Bass Coast Shire council Annual Report 2008 p. 39).
}

A low index is not necessarily an unfavourable outcome. For example, the element EN 16 Compliance records the incidents of and fines for non-compliance with all applicable international declarations/conventions/treaties, and national, regional and local regulations. Thus, if this item had a low SRDI, then that suggests that the local council has been compliant with international and local laws.

\section{Conclusion}

The objective of this research project was to investigate the incidence of environmental performance indicators in six Australian local councils that are located in coastal regions. These areas are characterised by a delicate natural environment and it is critical that adequate reporting is established so that this information can be used to at the very least, minimise environmental damage, but optimistically to sustain and improve what is already available.

Unsurprisingly, the overall level of disclosures was low. There are three possible explanations for this:

- the fact that the GRI Sustainability Reporting Guidelines and the sector supplements are voluntary and there is no legal or statutory obligation for public sector agencies to adhere to these, 


\section{Macrothink}

- the reporting of various sustainability indicators is a relatively new phenomenon still in its infancy for the public sector and,

- in relation to the second point, council officers require increased resources and specifically, training and education in order to fulfil the requirements of the GRI guidelines.

The findings from this study must be treated with caution. A low SRDI does not necessarily denote that these councils are not reporting sustainability activities, but may simply suggest that there have not been any significant unfavourable environmental impacts that need to be recorded. This is true for a number of indicators investigated such as EN 9 Use and emissions of ozone-depleting substances and EN 13 Significant spills of chemicals, oils and fuels.

In addition, some categories such as biodiversity and emissions, effluents and waste had nine indicators each making these SRDI low, compared with an element such as suppliers which has only one indicator and if disclosure is noted it would result in a higher percentage SRDI because it is coming from a low base figure.

One limitation of this study is that the identification of disclosures was limited to only environmental disclosures. Social disclosures were not identified because the focus of this study was local councils situated in coastal regions. These regions reside in a delicate web of natural flora, fauna, wetlands and ocean so it was anticipated that there would be greater disclosures on environmental indicators.

Further research could include a comparative study investigating how for example, urban local councils differ in their sustainability reporting with that of either rural councils or the councils studied for this project, that is, councils that are situated on the coastline. In addition, given the expediency that governments world wide are pressuring government and the private sector for more informed sustainability reporting, a longitudinal study investigating the changes (if any) as to the type and volume of sustainability disclosures would be a welcome addition to the literature. 


\section{References}

Adams, C.A. \& Gonzalez, C.L. (2007). Engaging with organisations in pursuit of improved sustainability accounting and performance. Accounting, Auditing \& Accountability Journal, 20:3, pp. 333-355.

Ball, A., \& Grubnic, S. (2007). Sustainability accounting and accountability in the public sector. In Unerman, J., Bebbington, J. \& O’Dwyer, B. (Eds), Sustainability Accounting and Accountability (Routledge, London).

Bebbington, J., Higgins, C. \& Frame, B. (2009). Initiating sustainable development reporting: evidence from New Zealand. Accounting, Auditing \& Accountability Journal, 22:4, pp.

588-625.

Campbell, D. (2000). Legitimacy theory or managerial reality construction? Corporate social disclosure in Marks and Spencer plc corporate reports 1969-1997. Accounting Forum, 24:1, pp. 80-100.

Cho, C. H., \& Patten, D.M. (2007). The role of environmental disclosures as tools of legitimacy: A research note. Accounting, Organizations and Society, 32:7-8, pp. 639-647.

Deegan, C., Rankin, M. \& Vought, P. (2000). Firms' disclosure reactions to major social incidents: Australian evidence. Accounting Forum, 24:1, pp. 101-130.

Global Reporting Initiative (GRI) (2005). Sector Supplement for Public Agencies, Amersterdam.

Global Reporting Initiative (GRI). (2006) . G3 Sustainability Reporting Guidelines. Amersterdam.

Gray, R., Kouhy, R. \& Lavers, S. (1995). Corporate social and environmental reporting: a review of the literature and a longitudinal study of UK disclosure. Accounting, Auditing \& Accountability Journal, 8:2, pp. 47-77.

Guthrie, J.E \& Mathews, M.R. (1985). Corporate Social Accounting in Australasia, Research in Corporate Social Performance and Policy, 7, pp. 251-77.

Guthrie, J \& Farneti, F. (2008). GRI sustainability reporting by Australian public sector organizations. Public Money and Management, 28:6, pp. 361-66.

Hopwood, A.G. (2009). Accounting and the environment. Accounting, Organizations and Society, 34:3-4, pp. 433-439. 


\section{Macrothink}

Lewis, T. (2008). Debate: Public sector sustainability reporting - implications for accountants. Public Money \& Management, 28:6, pp. 329-331.

Mathews, M.R. (1997). Twenty-five years of social and environmental accounting education. Accounting Education, 10:4, pp. 335-52.

Moneva, J.M \& Llena, F. (2000). Environmental disclosures in the annual reports of large companies in Spain. European Accounting Review, 9:1, pp. 7-29.

Moneva, J.M., Archel, P. \& Correa, C. (2006). GRI and the camouflaging of corporate unsustainability. Accounting Forum, 30:2, pp. 121-137.

Owen, D. (2008). Chronicles of wasted time? A personal reflection on the current state of, and future prospects for, social and environmental accounting research. Accounting, Auditing \& Accountability Journal, 21:2, pp. 240-267.

Wilmhurst, T. \& Frost, G. (2000). Corporate environmental reporting: a test of legitimacy theory. Accounting, Auditing and Accountability Journal, 3:1, pp. 10-26.

Yongvanich, K \& Guthrie, J. (2006). An extended performance reporting framework for social and environmental accounting. Business Strategy and the Environment, 15:5, pp. 309-321. 